\title{
Pengaruh Model Role Playing Terhadap Kemampuan Komunikasi Matematis Siswa Pada Materi Fungsi Komposisi Kelas XI Sma Negeri 6 Singkawang
}

\author{
Regita Wahyuni ${ }^{1)}$ Citra Utami ${ }^{2)}$ Nurul Husna ${ }^{3)}$ \\ 1) Program Studi Pendidikan Matematika STKIP Singkawang, Indonesia \\ E-mail:regitawahyuni03@gmail.com \\ 2) Program Studi Pendidikan Matematika STKIP Singkawang, Indonesia \\ E-mail:citrautami1990@gmail.com \\ 3) Program Studi Pendidikan Matematika STKIP Singkawang, Indonesia \\ E-mail:nuna_husna@ymail.com
}

\begin{abstract}
Abstrak. Penelitian ini bertujuan untuk: 1) mengetahui pengaruh model Role Playing terhadap kemampuan komunikasi matematis siswa. 2) mengetahui aktivitas belajar siswa terhadap model Role Playing. 3) mengetahui motivasi belajar siswa terhadap model Role Playing. Penelitian ini dilaksanakan di SMA Negeri 6 Singkawang.Adapun populasi dalam penelitian ini yaitu seluruh kelas XI yang terdiri dari XI IPA, XI IPS 1 dan XI IPS 2.Sampel dalam penelitian ini yaitu kelas XI IPS 2 sebagai kelas eksperimen dan kelas XI IPS 1 sebagai kelas kontrol. Penelitian ini menggunakan metode eksperimen dengan desain only control group design. Soal yang diberikan berupa essay terdiri dari 3 soal yang memuat indikator kemampuan komunikasi matematis siswa yang telah diuji cobakan terlebih dahulu dengan validitas, reliabilitas, daya pembeda dan tingkat kesukaran.Teknik analisis data yang digunakan untuk melihat pengaruh model Role Playing terhadap kemampuan komunikasi menggunakan rumus Effect Size, untuk mengetahui aktivitas belajar siswa dengan menghitung persentase indikator aktivitas belajar siswa dan untuk mengetahui motivasi belajar siswa menggunakan rumus rata-rata indikator motivasi. Hasil penelitian menunjukkan bahwa 1) pengaruh model Role Playing terhadap kemampuan komunikasi matematis siswa didapatkan hasil yaitu 0,29\% dengan kategori sedang. 2) aktivitas belajar siswa dengan diterapkan model Role Playing mencapai 77,91\% dengan kategori aktivitas belajar siswa tinggi. 3) motivasi belajar siswa diperoleh 3,98 dengan kategori motivasi belajar siswa ting gi.
\end{abstract}

Kata Kunci: Model Role Playing, Kemampuan Komunikasi Matematis

\section{PENDAHULUAN}

Matematika merupakan mata pelajaran pokok yang dipelajari pada tingkat dasar, menengah, atas bahkan perguruan tinggi. Lima alasan perlu belajar matematika karena matematika merupakan (1) sarana berpikir yang jelas dan logis, (2) sarana untuk memecahkan masalah dalam kehidupan sehari-hari, (3) sarana mengenal pola-pola hubungan dan generalisasi pengalaman, (4) sarana untuk mengembangakan kreativitas dan (5) sarana untuk meningkatkan kesadaran terhadap perkembangan budaya [1]. Matematika wajib untuk diajarkan terbukti matematika merupakan salah satu mata pelajaran yang termasuk pada Ujian Nasional (UN). Adapun tujuan pembelajaran matematika menurut Kurikulum Tingkat Satuan Pendidikan [2] satu diantaranya adalah mengkomunikasikan gagasan dengan simbol, tabel, diagram, atau media lain untuk memperjelas keadaan atau masalah.

National Council of Teacher of Mathematics (NCTM) menyatakan bahwa pembelajaran matematika di sekolah dari jenjang pendidikan dasar hingga kelas XII memerlukan standar pembelajaran yang berfungsi untuk menghasilkan siswa yang memiliki kemampuan berfikir, kemampuan penalaran matematis, memiliki pengetahuan serta keterampilan dasar yang bermanfaat. Satu diantara standar pembelajaran tersebut yaitu standar proses yang meliputi: pemecahan masalah, penalaran, komunikasi, penelusuran pola atau hubungan, dan representasi [3].

Kemampuan berkomunikasi merupakan penunjang keberhasilan siswa dalam mempelajari semua bidang studi yang terdapat di sekolah.Komunikasi matematis merupakan salah satu kemampuan yang harus dibekalkan kepada 


\section{- - - Jurnal Pendidikan Matematika Indonesia \\ Volum 1 Nomor 2 bulan September 2016. Halaman 81- 86 \\ p-ISSN: 2477-5967 e-ISSN: 2477-8443}

siswa dalam pelajaran matematika [4]. Kemampuan komunikasi matematis adalah suatu cara siswa untuk menyatakan dan menafsirkan gagasan-gagasan secara lisan maupun tertulis, baik dalam bentuk gambar, tabel, diagram, rumus atau demonstrasi [5].

Kemampuan komunikasi matematis siswa perlu dikembangkan, sebagaimana diungkapkan Baroody [6] bahwa sedikitnya ada dua alasan penting mengapa komunikasi dalam pembelajaran matematika perlu ditumbuhkembangkan di sekolah. Pertama adalah matematika tidak hanya sekedar alat bantu berfikir, alat untuk menemukan pola, menyelesaikan masalah atau mengambil keputusan tetapi matematika juga sebagai alat untuk mengkomunikasikan berbagai ide dengan jelas, tepat dan ringkas. Kedua adalah sebagai aktivitas sosial dalam pembelajaran matematika di sekolah, matematika juga sebagai tempat interaksi antar siswa dan juga sebagai sarana komunikasi guru dan siswa.

Namun pada kenyataanya kemampuan komunikasi matematis siswa selama ini masih tergolong rendah.Siswa sulit untuk mengkomunikasikan ide-ide mereka.Selama peneliti praktek pengalaman lapangan terlihat bahwa siswa belum berani mengungkapkan ide atau gagasannya didepan kelas ketika guru menyuruh maju. Aktivitas siswa selama proses pembelajaran ikut berpengaruh terhadap kemampuan komunikasi matematis siswa [7]. Dalam proses pembelajaran siswa cenderung datang ke kelas hanya untuk datang dan mendengarkan sehingga tidak terjadi komunikasi antara siswa dan guru atau antar siswa itu sendiri. Siswa enggan bertanya kepada guru maupun temannya ketika mengalami kesulitan dalam belajar. Permasalahan tersebut mengambarkan bahwa motivasi siswa terhadap pembelajaran matematika kurang, siswa terkadang tampak bermain-main dengan temannya sehingga tidak mendengarkan penjelasan guru.Sehingga hal tersebut menjadi salah satu faktor rendahnya kemampuan komunikasi matematis siswa.

Rendahnya kemampuan komunikasi matematis siswa terbukti dari hasil observasi selama peneliti praktek pengalaman lapangan di SMA Negeri 6 Singkawang didapatkan informasi bahwa pembelajaran matematika yang dilakukan di sekolah belum sepenuhnya dapat mengembangkan kemampuan komunikasi matematis, pembelajaran matematika umumnya masih berlangsung secara konvensional dengan karakteristik berpusat pada guru.Berdasarkan hasil wawancara dengan guru mata pelajaran matematika di SMA Negeri 6 terungkap beberapa permasalahan yang diduga sebagai penyebab rendahnya kemampuan komunikasi matematis siswa adalah siswa kurang percaya diri dalam mengkomunikasikan gagasannya selain itu pada saat guru menjelaskan siswa tidak memperhatikan dengan baik, siswa juga sering salah menafsirkan soal yang diberikan.Selain itu, hasil prariset siswa belum mencapai KKM.

Oleh karena itu, diperlukan suatu upaya untuk meningkatkan kemampuan komunikasi matematis siswa, misalnya dengan memilih dan menggunakan berbagai pendekatan, strategi, metode dan model pembelajaran yang relevan dengan kondisi siswa. Satu diantara model pembelajaran matematika yang dapat digunakan untuk mengatasi masalah rendahnya kemampuan komunikasi matematis siswa adalah dengan menggunakan model Role Playing. Model Role Playing adalah rangkaian kegiatan yang menekankan pada kemampuan kerja sama, komunikatif dan menginterpretasikan suatu kejadian [8].

Berdasarkan uraian di atas maka peneliti tertarik menerapkan model Role Playing untuk meningkatkan kemampuan komunikasi matematis siswa, maka peneliti akan melakukan penelitian dengan judul "Pengaruh Model Role Playing Terhadap Kemampuan Komunikasi Matematis Siswa Pada Materi Fungsi Komposisi Kelas XI SMA Negeri 6 Singkawang".

\section{METODE}

Metode penelitian ini adalah metode eksperimen dengan menggunakan desain Trueeksperimental.Rancangan yang digunakan adalah Posttest-Only Control Desain.Adapun populasi dalam penelitian ini adalah seluruh siswa kelas XI IPS SMA Negeri 6 Singkawang tahun ajaran 2015/2016 sebanyak 3 kelas yaitu kelas XI IPA sebanyak 20 siswa, XI IPS 1 sebanyak 30 siswa 
dan XI IPS 2 sebanyak 30 siswa.Sedangkan sampel dalam penelitian ini adalah kelas XI IPS 2 sebagai kelas eksperimen dan kelas XI IPS 1 sebagai kelas kontrol.Pengambilan sampel dengan menggunakan teknik Purposive Sampling.

Jenis penelitian ini adalah jenis penelitian kuantitatif dengan metode eksperimen karena data yang diperoleh berhubungan dengan angka-angka yang dapat dihitung secara matematis dan sistematis.Penelitian ini menggunakan desain penelitianPosttest-Only Control Desaign.Populasi dalam penelitian ini adalah seluruh siswa kelas VIII SMA Negeri 6 Singkawang yang berjumlah 30 siswa.Sedangkan sampel dalam penelitian ini adalah kelas XI IPS 2 sebagai kelas eksperimen yang berjumlah 30 siswa dan kelas XI IPS 1 sebagai kelas kontrol yang berjumlah 31 siswa.Teknik pengambilan sampel yang digunakan dalam penelitian ini adalahteknik Purposive Sampling.

Teknik pengumpulan data yang dimaksud dalam penelitian ini adalah dengan memberikan tes, yaitu tes akhir (post-test) kepada siswa mengenai materi fungsi komposisi, tes yang digunakan dalam penelitian ini berbentuk uraian (essay) yang terdiri dari 3 butir soal. Observasi dalam penelitian ini digunakan untuk mengetahui aktivitas belajar siswa selama proses pembelajaran dengan menggunakan model Role Playingpada materi fungsi komposisi. Angket digunakan untuk mengetahui motivasi belajar siswa dengan menggunakan lembar angket motivasi belajar siswa yang terdiri dari 10 pernyataan berbentuk pilihan dengan tanda check list $(\sqrt{ })$. Dokumentasi bertujuan untuk menggambarkan secara visual kondisi selama pembelajaran dengan menggunakan model Role Playing.

Instrumen pengumpulan data dalam penelitian ini berupa soal tes kemampuan komunikasi matematis, lembar observasi, lembar angket dan dokumentasi.Instrumen pengumpulan data berupa tes terlebih dulu di uji validitas, reliabilitas, daya pembeda dan tingkat kesukarannya.Validitas bertujuan agar tes yang digunakan benar-benar untuk mengukur kemampuan siswa dalam menyelesaikan soal fungsi komposisi, maka instrumen yang telah disusun diukur dengan validitas tes.Adapun hasil perhitungan validitas dapat dilihat pada Tabel 1.Perhitungan Validitas Uji Coba Soal berikut ini.

TABEL I

PERHITUNGAN UJI COBA SOAL

\begin{tabular}{lllllll}
\hline \multirow{2}{*}{ Soal } & Nomor & Nomor & Nomor & Nomor & Nomor & Nomor \\
& $\mathbf{1 A}$ & $\mathbf{1 B}$ & $\mathbf{2}$ & $\mathbf{3 A}$ & $\mathbf{3 B}$ & $\mathbf{3 C}$ \\
Validitas & 0,41 & 0,43 & 0,54 & 0,61 & $.0,52$ & 0,61 \\
Kriteria & Cukup & Cukup & Cukup & Tinggi & Cukup & Tinggi \\
\hline
\end{tabular}

Reliabilitas menunjukkan pada suatu pegertian bahwa suatu instrumen cukup dapat dipercaya untuk digunakan sebagai alat pengumpulan data karena instrumen tersebut sudah baik. Berdasarkan hasil perhitungan uji coba soal diperoleh bahwa reliabilitas sebesar 0,43 dengan kriteria sedang.Sedangkan daya pembeda adalah kemampuan dari tes tersebut dalam memisahkan antara subjek yang pandai dengan subjek yang kurang pandai.Adapun hasil perhitungan daya pembeda dapat dilihat pada Tabel 2.Perhitungan Daya Pembeda Uji Coba Soal sebagai berikut.

TABEL 2

PeRhitungan DAYA PEMBEDA Uji CoBA

\begin{tabular}{lllllll}
\hline Soal & Nomor & Nomor & Nomor & Nomor & Nomor & Nomor \\
& $\mathbf{1 A}$ & $\mathbf{1 B}$ & $\mathbf{2}$ & $\mathbf{3 A}$ & $\mathbf{3 B}$ & $\mathbf{3 C}$ \\
DP & 0,38 & 0,38 & 0,38 & 0,55 & 0,44 & 0,55 \\
Kriteria & Cukup & Cukup & Cukup & Tinggi & Tinggi & Tinggi \\
\hline
\end{tabular}

Tingkat kesukaran bertujuan untuk mengkaji soal-soal soal tes yang diuji cobakan dari sisi kesulitannya, sehingga dapat diperoleh soal-soal yang termasuk dalam kategori mudah, sedang dan sukar.Adapun hasil perhitungan tingkat kesukaran dapat dilihat pada Tabel 3.Perhitungan Tingkat Kesukaran Uji Coba Soal sebagai berikut.

TABEL 3

Perhitungan TingKat KesuKaran Uji CoBA SoAL

\begin{tabular}{ccccccc}
\hline \multirow{2}{*}{ Soal } & Nomor & Nomor & Nomor & Nomor & Nomor & Nomor \\
& $\mathbf{1 A}$ & $\mathbf{1 B}$ & $\mathbf{2}$ & $\mathbf{3 A}$ & $\mathbf{3 B}$ & $\mathbf{3 C}$ \\
$\boldsymbol{T K}$ & 0,46 & 0,59 & 0,46 & 0,45 & 0,42 & 0,42 \\
Kriteria & Sedang & Sedang & Sedang & Sedang & Sedang & Sedang \\
\hline
\end{tabular}

\section{HASIL DAN PEMBAHASAN}

HASIL

Dari rekapitulasi perhitungan hasil posttest siswa, dapat dilihat bahwa nilai rata-rata hasil posttest kelas eksperimen lebih tinggi dari pada nilai rata-rata hasil posttest kelas kontrol.Rata-rata hasil tes kemampuan komunikasi matematis siswa pada kelas yang diberikan perlakuan dengan menggunakan model pembelajaran Role Playing 
lebih tinggi daripada rata-rata hasil tes kemampuan komunikasi matematis siswa pada kelas yang tidak diberikan perlakuan $(73>63)$. Kemudian untuk mengetahui besar pengaruhnya data tersebut dihitung dengan menggunakan rumus Effect Size sehingga didapatkan hasil pengaruhnya sebesar 0,29\% dengan kategori sedang.Adapun hasil selengkapnya dapat dilihat pada Tabel 4. sebagai berikut.

TABEL 4

NILAI POSTTEST KELAS EKSPERIMEN DAN KELAS KONTROL

\begin{tabular}{ccc}
\hline & $\begin{array}{c}\text { Kelas } \\
\text { Eksperimen }\end{array}$ & $\begin{array}{c}\text { Kelas } \\
\text { Kontrol }\end{array}$ \\
\hline Rata-Rata & 75 & 63 \\
Standar Deviasi & 112,1 & 40,9 \\
Effect Size & \multicolumn{2}{c}{$0,29 \%$} \\
Kategori & \multicolumn{2}{c}{ Sedang }
\end{tabular}

Berdasarkan perhitungan data aktivitas pada lembar pengamatan aktivitas selama proses pembelajaran dengan menggunakan model Role Playing, tingkah laku siswa dibagi ke dalam 2 kategori yaitu tingkah laku aktif dan tingkah laku pasif. Hasil data pengamatan aktivitas siswa pada saat proses pembelajaran menggunakan model Role Playing, untuk pertemuan pertama persentase tingkah laku siswa aktif pada kategori 1, 2, 3 adalah 70,83\%, sedangkan untuk persentase tingkah laku siswa pasif pada kategori 4, 5, 6 adalah $17,53 \%$. Pertemuan kedua untuk persentase tingkah laku siswa aktif pada kategori 1, 2, 3 adalah $85,14 \%$, sedangkan persentase tingkah laku siswa pasif pada kategori 4, 5, 6 adalah18,27\%. Adapun persentase aktivitas belajar siswa pada pertemuan pertama dan kedua disajikan pada Tabel 5.berikut ini.

\begin{tabular}{cccc}
\hline \multirow{2}{*}{ Keterangan } & \multicolumn{2}{c}{ Kelas Eksperimen } & Kategori \\
\cline { 2 - 3 } & Pertemuan 1 & Pertemuan 2 & \\
\hline $\begin{array}{c}\text { Tingkah Laku } \\
\text { Aktif }\end{array}$ & $70,83 \%$ & $85,14 \%$ & Tinggi \\
\hline Jumlah & \multicolumn{2}{c}{$77,99 \%$} & \\
\hline $\begin{array}{c}\text { Tingkah Laku } \\
\text { Pasif }\end{array}$ & $17,53 \%$ & $18,27 \%$ & Sangat \\
& & Rendah \\
\hline Jumlah & \multicolumn{2}{c}{$17,9 \%$} & \\
\hline
\end{tabular}

Berdasarkan hitungan persentase pada lembar angket motivasi belajar siswa selama proses pembelajaran dengan menggunakan model pembelajaran Role Playing dapat diketahui motivasi belajar siswa tinggi. Adapun persentase motivasi belajar siswa disajikan pada Tabel 6.berikut ini.

TABEL 6

HASIL ANGKET MOTIVASI BELAJAR SISWA

\begin{tabular}{cc} 
Jumlah rata-rata item & 1194 \\
Rata-Rata Keseluruhan & 3,98 \\
Kriteria & Motivasi Tinggi \\
\hline
\end{tabular}

PEMBAHASAN

Faktor yang mempengaruhi kemampuan komunikasi matematis siswa adalah penerapan model pembelajaran Role Playing dengan rangkaian kegiatan pembelajaran yang menarik, siswa dapat mengkomunikasikan ide-idenya dalam bentuk gambar, tulisan maupun simbol sehingga kemampuan komunikasi matematis siswa meningkat.Hal ini sejalan dengan teori belajar Bruner yang menyatakan bahwa apa yang dilakukan manusia dengan informasi yang diterimanya dan apa yang dilakukannya sesudah memperoleh informasi yang diskret untuk mencapai pemahaman yang memberikan kemampuan kepadanya. Sehingga dapat disimpulkan pembelajaran dengan menggunakan model Role Playing pada materi fungsi komposisi dikatakan dapat memberikan pengaruh terhadap kemampuan komunikasi matematis siswa sebesar 0,29 dengan kategori sedang.

Sedangkan faktor yang mempengaruhi aktivitas belajar siswa tinggi adalah model pembelajaran Role Playing yang menekankan kepada 
kemampuan bekerja sama, komunikatif dan menginterpretasikan suatu kejadian. Selain itu, model Role playing sangat menarik bagi siswa sehingga memungkinkan kelas menjadi dinamis dan penuh antusias.Hal ini sejalan dengan teori belajar Gagne yang menyatakan bahwa keterampilan intelektual memungkinkan seseorang berinteraksi dengan lingkungannya menggunakan simbol-simbol atau gagasan-gagasan.

Setelah proses belajar dengan model pembelajaran Role Playing selesai, siswa diberikan angket motivasi belajar untuk mengetahui motivasi belajar siswa selama proses pembelajaran berlangsung, siswa hanya memilih salah satu pernyataan yang telah disediakan. Sebelum diberikan model pembelajaran Role Playing motivasi belajar siswa masih tergolong rendah dan setelah diterapkan model pembelajaran Role Playing motivasi belajar siswa tinggi.Faktor yang mempengaruhi motivasi belajar siswa tinggi adalah penerapan model pembelajaran Role Playing membuat kelas menjadi dinamis dan antusias.Sehingga siswa termotivasi untuk mengikuti pembelajaran pada materi komposisi fungsi. Hal ini sejalan teori belajar Gagne yang menyatakan bahwa keterampilan motorik tidak hanya mencakup kegiatan fisik tetapi juga kegiatan motorik yang digabung dengan keterampilan intelektual sehingga menumbuhkan motivasi belajar pada saat proses pembelajaran berlangsung.

Dari uraian tersebut, model Role Playing merupakan satu diantara model yang dapat melatih kemampuan komunikasi matematis siswa dan membantu siswa lebih aktif dalam pembelajaran sehingga siswa termotivasi untuk belajar. Sebelum model Role Playing diterapkan kemampuan komunikasi matematis siswa dengan indikator kemampuan menyatakan gagasan dalam bentuk gambar, kemampuan menyatakan gagasan dalam bentuk notasi atau simbol dan kemampuan menyatakan gagasan dalam bentuk kalimat di kelas XI SMA Negeri 6 Singkawang masih tergolong rendah, selain itu aktivitas dan motivasi belajar siswa juga tergolong rendah. Setelah diterapkan model Role Playing kategori kemampuan komunikasi matematis siswa tergolong cukup baik dan terdapat aktivitas belajar yang baik serta motivasi belajar siswa sangat tinggi.

\section{KESIMPULAN DAN SARAN}

KESIMPULAN

Berdasarkan hasil pengolahan data penelitian yang dilakukan, secara umum dapat disimpulkan bahwa terdapat pengaruh yang positif model pembelajaran Role Playing terhadap kemampuan komunikasi matematis siswa pada materi fungsi komposisi kelas XI SMA Negeri 6 Singkawang. Secara khusus dapat disimpulkan bahwa terdapat pengaruh model Role Playing terhadap kemampuan komunikasi matematis siswa pada materi komposisi fungsi sebesar 0,29\% dengan kategori sedang, aktivitas belajar siswa tinggi terhadap model Role Playing sebesar 77,99\% dengan kategori tinggi, motivasi belajar siswa tinggi terhadap model Role Playing sebesar 3,98 dengan kategori tinggi.

SARAN

Model Role Playing sebaiknya digunakan sebagai satu diantara alternative model pembelajaran yang dilaksanakan di sekolah, sebab model Role Playing dapat memberikan pengaruh yang positif terhadap kemampuan komunikasi matematis siswa. Selain itu, model Role Playing dapat diterapkan di sekolah lain untuk mengetahui aktivitas belajar siswa di sekolah yang berbeda. Model Role Playing dapat diajarkan pada materi lain tidak hanya pada materi fungsi komposisi. Selain itu, guru sebaiknya menjelaskan kepada siswa agar tidak takut membuat kesalahan dalam kegiatan pembelajaran dengan menggunakan model Role Playing karena banyak siswa yang cenderung takut untuk mencoba.

\section{UCAPAN TERIMAKASIH}

Penulis mengucapkan terima kasih kepada dosen pembimbing yaitu Citra Utami, M.Pd selaku dosen pembimbing I dan Nurul Husna, M.Pd selaku dosen pembimbing II yang telah membimbing, memberikan saran, masukan serta pengarahan penulis, sehingga penulis dapat menyelesaikan jurnal ini.Kemudian penulis juga mengucapkan terima kasih kepada STKIP Singkawang yang telah mendukung dan 
mamfasilitasi penulis dalam menyelesaikan jurnal ini.

\section{DAFTAR PUSTAKA}

[1] Fahradina, dkk.2014. Peningkatan Kemampuan Komunikasi Matematis dan Kemandirian Belajar Siswa SMP dengan Menggunakan Model Investigasi Kelompok. Syiah Kuala: Jurnal Universitas Syiah Kuala.

[2] Depdiknas. 2006. Tujuan Kurikulum Tingkat Satuan Pendidikan. Jakarta: Depdiknas.

[3] Rachmayani, Dwi. 2014. Penerapan Pembelajaran Reciprocal Teaching Untuk Meningkatkan Kemampuan Komunikasi Matematis Dan Kemandirian Belajar Matematika Siswa. Jakarta: Jurnal Pendidikan UNSIKA Volume 2 Nomor 1.

[4] Fitriani, Dulis. 2003. Meningkatkan Kemampuan Komunikasi Matematik Siswa SMP Dengan Pembelajaran Student Facilicator And Explaining. Siliwangi: Jurnal STKIP Siliwangi.

[5] Prayitno, dkk. 2013. Identifikasi Indikator Kemampuan Komunikasi Matematis Siswa Dalam Menyelesaikan Soal Matematika Berjenjang Pada Tiap Jenjangnya. Surabaya: Jurnal Universitas Negeri Surabaya.
[6] Husna, dkk. 2013. Peningkatan Kemampuan Pemecahan Masalah Dan Komunikasi Matematis Siswa Sekolah Menengah Pertama Melalui Model Pembelajaran Kooperatif Tipe Think-PairShare(TPS). Aceh: Jurnal Unsyiah.

[7] Suandika, Putu. 2014. Penerapan Model Pembelajaran Snowball Throwing Berbantuan Media Lingkungan Untuk Meningkatkan Aktifitas Dan Hasil Belajar IPA Siswa Kelas III SD. Jurnal Mimbar PGSD Universitas Pendidikan Ganesha Jurusan PGSD (Volume:2 No:1 Tahun 2014).

[8] Sutikno, Sobry. 2014. Metode \& Model-Model Pembelajaran Lombok: Holistica.

[9] Anggraeni, Dian dan Sumarno, Utari. Meningkatkan Kemampuan Pemahaman Dan Komunikasi Matematik Siswa SMK Melalui Pendekatan Kontekstual Dan Strategi Formulate-Share-ListenCreate(FSLC).Bandung: Jurnal Ilmiah Program Studi Matematika STKIP Siliwangi Bandung. 